\title{
THE FORGOTTEN SOMALIA: A KEY FACTOR FOR PEACE AND STABILITY IN THE HORN OF AFRICA
}

\author{
Dr. Simonetta Silvestri, Security Policy Advisor
}

\begin{abstract}
Since colonial times, Somalia has been going through authoritarian and/or democratic transitions. The transitory position of Somalia was determined by geography, religion, ethnicity, tribal origins, socio-economic, and political system. Somalia is one of the longest protracted crises in the world and recurrently victim of the violent extremism that breathes into the political, social and economic country's unrest. Somalia remains a major threat to peace and stability in the Horn of Africa. More importantly, continuous uprisings, violence, and conflicts threaten peace, stability, and security in Somalia. This paper examines the root causes of these developments by considering international, regional and domestic actors in state security, peace, and stability. How tackling of terrorism, extremism and organized crime are conditioned by the effectiveness of the system of governance, the rule of law, economic growth and development and, more importantly, state security, police, and defense. This paper also placed the questions of terrorism and conflict within a global security framework and the fight against terrorism, organized crime, and illegal human trafficking and migrations.
\end{abstract}

Keywords: security, governance, peace, state-building, ideology. 


\section{Introduction}

The uprising in 1986 against the regime of Siad Barre characterized the beginning of the Somalia civil war till 1991. When Siad Barre was dismissed from the power the conflict expanded among Somalia warlords. In response to the humanitarian crises and the ongoing conflict in 1992 the United Nations with the Security Council Resolution 792/1992 (UNSCR) established the United Task Forces, UNITAF, for Operation Restore Hope led by established the United Nations Operations in Somalia, UNOSOM I from April 1992 to March 1993 with the UNSCR 733/1992 and UNOSOM II from March 1993 to March 1995 with the UNSCR 794/1992 the USA (December 1992 - May 1993) and contemporary. The UNSCR reaffirmed the UN commitment to the ceasefire, humanitarian assistance, and tackling of the threats to peace and security.

Between 2000 and 2008 the Somali government was challenged by the Union of the Islamic Courts (UIC) Midowga Maxkamadaha Islaamiga and the militant wing of Al Shabaab link to Islamic terrorism of Al Qaeda. From the year 2008 to 2012, in spite the strong resistance of the Somali's central government, Somalis reached an agreement on a government of national transition under which Somalia moved in 2012 from a centralized to a federal government of six states, divided into eighteen administrative regions or also called gobollada, which in turn are subdivided into districts. In June 2013, eighteen years later from the United Nations Operations in Somalia the United Nations Security Council with the Security Council Resolution 2102/2013 deployed the United Nations Assistance Mission in Somalia, UNSOM, a political mission mandated to support the state building and the peace process in the country, allowing humanitarian aids to reach a population affected by decades of civil war. The United Nations Assistance Mission supported the Federal Government of Somalia by providing the strategic policy on peace-building and state-building in terms of effective governance, security reforms, rule of law, the functioning of the federal system, constitutional reforms and fair and transparent elections. Then, the UN was mandated to bring Somalis together to rebuild the country in what Staub defines

"common goals": the strengths of the existing groups' identities and previous successes in achieving joint goals affect the extent to which intergroup cooperation reduces conflict and results in positive ties. By focusing on common goals, there is a greater likelihood of successful outcomes which will, in turn, contribute to the nurturing of a positive outlook on the other, thereby resulting in greater trust and caring towards each other, which will promote social cohesion and develop nationalism.

UNSOM 's mandate has been renewed up to the UNSCR 2408/2018 till March 2019 due to the challenges the Federal Republic of Somalia is facing consolidating state formation and federalism. In fact, beside the challenges posed by Al Shabaab Somalia remains extremely divided internally due to clans fighting for territorial power, federal resources appropriation, and federal members states conflicts and armed clashes over borders like Somaliland and Puntland on the contentious issue of Sool, Sanaag and Ayn or Puntland and Galmudug over the divided city of Gaalkacyo for instance. The destabilizing factor that the inter-regional conflicts can bring about is generally underestimated. The International Crisis Group reported:

Somalia's foreign partners appear to underestimate the risk of conflict in the north. They tend to assess the north's stability in reference to the south - a low bar that may have meant warning signs slipped under the radar. That the crisis has deteriorated almost to the point of open war speaks to a number of realities. Outside powers have mostly preferred "positive" narratives that oversell the north's recovery - and that of Somalia more broadly - and downplay risks. Leaders in both Puntland and Somaliland appear wedded to brinksmanship and believe they have little incentive to make peace. Local and international mediation systems are disjointed and mostly reactive. Puntland and Somaliland are sliding toward a protracted conflict with enormously destabilising consequences for not only northern Somalia but the country as a whole. War is still avoidable, but to forestall it both sides need to take a step back, dial down their rhetoric and allow for mediation led by the UN. Their long-running dispute over Soog and Sanaag regions will inevitably take time to resolve. But the priority today is for the two sides to deescalate, arrive at some modus vivendi and accept a mechanism for determining that status. The alternative is a war in northern Somalia that would be extremely costly to both sides, tarnish their international reputations, worsen an already grave humanitarian predicament and undercut efforts to counter Al-Shabaab and the small, but deadly ISIS branch in Puntland. 


\section{State of Security in the Federal Republic of Somalia}

The state of Somalia collapsed for almost two decades under the attacks of Al Shabaab violent extremism, preventing the country's economic, political and social development and has increased the radicalization of young Somalis deprived of life opportunities. Somalia is the hub for piracy, illegal fishing, human trafficking, import and export of charcoal, arms and ammunition trafficking, import and export of oxidisers use for the improvised explosive devices used by Al Shabaab in its terrorist attack against security forces and civilians. Back in 2006 with the Security Council Resolution 1725/2006, the African Union peacekeeping operation AMISOM entered Somalia to maintain and support the peace process and re-conquers the territories controlled by Al Shabaab. The loss of numerous lives of the Ugandans, Burundians, Sierra Leon, Kenyans, Ethiopians soldiers of the African Union extensively proved the 12 years commitment of the regional organization to restore peace in Somalia and the region but without fully succeed in defeating Al Shabaab. AMISOM peacekeeping operation reached the number of 25.000 units in 2016 and from 2017 has initiated the downsizing leaving the Somali National Army and the Somali Police Forces to replace the AMISOM.

Often the territories liberated by the AMISOM's troop were quickly regained by AI Shabaab that effectively and efficiently provides services to the communities exploiting the absence of the central and federal government to advance its goal and set up a fundamentalist regime terrorizing Somali's institution and civilians across the country and in the region. Somali's central governance and Federal states continue to struggle in providing services to those communities liberated by the African Union favoring Al Shaabab return and its quick response to counter community's need. Contrary to international organizations Al Shabaab does not have to go through any government's channel, to deliver aid because it can easily approach communities in a bottom up approach enshrining in the community. On the contrary, the international organizations, such as the European Union, USAID, and the United Nations, must go through government institutions to deliver aid or provide support to the communities in a top down approach that often does not expose them directly to the communities and most of all it is not perceived and received by the communities.
The Al Qaeda affiliated group Al-Shabaab (AS) are constantly engaged in fighting by AMISOM forces throughout Somalia. Strongholds for AS include extensive parts of Jubba, and in pockets of Galmuduud and Puntland. AS has predominantly been restricted to asymmetrical attacks across the country, which were aimed at the security forces and civilians. The most recent attacks of $26^{\text {th }}$ November, claimed by Al Shabaab, targeted the Mogadishu city centre and the northern city of Galkayo, 24 people lost their lives in the attacks.

Al Shabaab continues to demonstrate its ability to launch high profile attacks against state institutions, buildings and hotels, particularly in Mogadishu. Although Al Shabaab suffered significant losses and displacement from main bases in areas such as Dinsoor and Bardheere they enlarge the presence in peripheral districts of Mogadishu of specialized cells to conduct asymmetric attacks, possibly to deflect attention from operations in Southern Somalia. AS increased the number of armed fighters for planned complex attacks. Their attack procedures showed evolution and possibly an indication of their intent to continue to use a system, the large complex attacks, that has shown positive results since its introduction in June 2015, successfully conducted against the Somali National Army (SNA) and Kenyan Defence Force (KDF). Having lost physical control of key areas, including revenue-generating ports such as Kismayo and Barawe, and a number of key leaders, AS has become more focused on terrorist activity and has changed its capability, including types of fighters and weaponry. Well-planned targeted political assassinations, as well as attacks on security forces and foreign presence, are currently the main actions undertaken, including in Mogadishu. Just depriving AS of its vast areas of territorial control is not expected to result in an effective end to its activities in Somalia. It has proved resilient and is also now well embedded in neighboring states, including Kenya, where it can conduct both operations and "back office" activities. The war in Yemen potentially opens up new opportunities for AS, given its long-standing and trusted links with Al Qaeda in the Arabian Peninsula (AQAP). In particular, there is a risk of easier transit for terrorist fighters and easier access to arms supplies from Yemen through Somaliland. Although the so-called Islamic State (ISIS) has attempted to change the allegiance of AQ (and have had some success at the tactical level) it is unlikely that the AS leadership will take such a step. The Yemen crisis 
has the potential to significantly alter the regional dynamics. A clearly focused Yemen analysis, definition of EU objectives, and subsequent measures to address this issue may become key to a broader response.

\section{Fighting Terrorism and Transnational Organized Crime}

Somalia's internal instability is a threat to peace and security in the region also due to the porous border and the uncontrolled $3,300 \mathrm{~km}$ of maritime coast due to the lack of maritime security forces infrastructure. The Somali coastline is the longest in Africa and has three major ports, Berbera in Somaliland, Bosasso in Puntland and Kismayo in Jubaland, which are often illegally used to traffic illegal weapons, charcoal, livestock, and agricultural products as sources of revenue to finance $\mathrm{Al}$ Shabaab. The conflict in Yemen has also increased the arms trafficking in Berbera, Somaliland as a route for transport in and out of Somalia. Somalia is under the Security Council Sanction 2385/2017 on Arms embargo, chemical weapons and import and export of charcoal to and from Somalia. Al Shabaab (AS) continues to remain a significant threat to internal stability and security in Somalia, though the nature of that threat has changed.

President Mohamed Abdullahi Farmaajo, elected in February 2017, adopted a national strategy to counter violent extremism within a new national security architecture engaging civil society, the private sector and overall the entire community sending a clear signal to endure in the fight against terrorism. The Somali Police Forces supported by the Somali National Army will be left to continue the fight against terrorism, meanwhile a renew attempt to tolerance, dialogue, and peace has to prevail in Somalia as well as in the region. The National Security Policy, National Threat Assessment and National Policing model in Somalia highlight the need to move from a military-led offensive, against Al-Shabaab, to civilian law enforcement in order to stabilize the country, implementing the rule of law, enabling basic service-delivery and provide the opportunity to the local communities. This broad policy framework has been created for this shift to occur, and the support of the international community is needed to move forward. The United Nations and the European Union are contributing to this effort, by means of mentoring and giving advice for improved governance and institutional capacity to key line-ministries and related law-enforcement agencies tasked to implement the National Security Policy and the National Policing
Model. These frameworks reflect the priorities of Somali authorities, requesting support to the international community to the development of law-enforcement capacity, with a special focus on capacity in regional administrations. Maritime security is one element of the frameworks; however, the biggest gaps and opportunities for significant contribution remain on land, addressing structural challenges, which are key to tackling law-enforcement and governance more holistically. Fighting violent extremism remained a priority for Somalia and for the governments in the region and to counter violent extremism military actions are not sufficient neither preventive. Terrorism exploits governance, poverty, and illiteracy and cannot be fought just with an army; there must be others. Somalis are $100 \%$ Sunni-Muslims with the right and peaceful interpretation of Islam and a community that struggles to get involved and participate in the political, economic and social development of the country to promote peace and security.

The Organization for Economic Co-operation and Development (OECD) reports that 740.000 people die because of armed conflict each year and it also seriously undermines the attainment of the Millennium Development Goals. Armed conflict and violence undermine peace-building, state-building, development and an effective system of governance. Therefore, addressing the terrorism within the armed violence reduction under the principle listed above might effectively contribute to restoring peace and security.

Somalia continues to be seen as a treat to international peace and security in the region and in the world. In agreement with Kizito Sabala, Aisha Ahmad \& Edwin Rutto "domestic conflicts have a propensity to become internationalized. Neighboring states are drawn into conflict through refugee flows, humanitarian crises and the trafficking of arms." Somalia remains a major threat to security in the Horn of Africa. Securing the peace of Somalia is the most critical task ahead of this government because Somalia's domestic threats and internal security negatively affect region development, peace, and stability. Brutal attacks of violent extremism were conducted in Somalia and outside Somalia territory. Lidwien Kapteijn considers that in Somalia, as for former Yugoslavia and Rwanda, armed violence broke down law and order, sweeping away many people's adherence to normative ethical behavior and cultural script. Kapteijn argued that "the orchestration 
of violence against civilian operated from Al Shabaab is consciously used as a political instrument: in the absence of another public agenda than their own groups' political dominance, they could envision no role for member defined as "other"; simple logic demanded their removal." Al Shabaab as any other terrorist group in their attempt to change the political and social dimension used the same political instruments, violence, of those regime/leaders they attempt to remove.

As attacks increasingly showed the need for the neighboring countries to strategically address the fight against terrorism and transnational organized crime through which terrorism is often funded especially after AS pledged allegiance to Al Qaeda increasing the fear of violent extremism and terrorism threats both in Somalia and to the wider region. There is evidence of Da'esh courting AS allegiance in particular in the northern parts of Somalia. To add, as the military conflict against Da'esh progresses in Syria, and Iraq, there is a potential risk that foreign terrorist fighters may either return to their homelands or look towards other 'permissive' areas/countries and potentially impacting on the Horn of Africa region and its dynamics with AS. Gulf's state political influence strongly grows influencing Somalia and the Horn of Africa political development and it is likely to continue to grow as wider regional dynamics involving other key partners such as Turkey, Ethiopia and recently Egypt play out in Somalia. Thus, Somalia's security and stability is vital for the larger Horn of Africa region and beyond. The protracted crisis in South Sudan degenerated, the continued crisis in Yemen might further affect Somalia's instability.

\section{Security and Development Nexus}

In the modern history of Somalia, Lewis considers that regeneration of social cohesion and nationalism, as opposed to the sectarian nature of Somalis, is one of the main challenges Somalia has ahead, considering that Somalis share the same language, culture, and religion. It will take time for President Framajo to rebuild the state's credibility among Somalis because the state itself failed in protecting it's individual's interests and security. The rebuilding of security governance is not a process in isolation: the security process needs to go along with the development process due to the nexus between the two. Fundamental to this is that the longterm solution for Somalia's security lies in the creation of capable and accountable national armed forces in the form of the Somali national and rapid economic development to offer employment opportunities preventing terrorism recruitment. With a young population and limited employment opportunities, economic development can create employment reducing the chance of radicalization and ensure that Somali security institutions are affordable for the country in the long term. In Somalia, the regained territories from AS must see the benefits of development assistance to change perceptions and reduce the breeding ground for extremists.

According to the World Bank in November 2018, Somalia's gross domestic product (GDP) growth weakened in 2017 due to the severe drought. Although Somalia averted widespread famine in 2017, the drought led to large-scale food insecurity, affecting more than six million people. More than half of the population lives in poverty and a large proportion is sensitive to negative shocks. GDP growth declined to $2.3 \%$ in 2017 , compared to $4.4 \%$ in 2016 . Economic activity is mainly anchored in agriculture and the services sector. The agriculture sector experienced neartotal collapse with crop failures, a widespread shortage of water and pasture, and increased livestock mortality. Inflationary pressure increased in 2017 due to droughtdriven by significant increases in crop prices. Implementation of fiscal policy has significantly improved, but challenges remain. Domestic revenue grew by $26.5 \%$, from $\$ 112.7$ million in 2016 to $\$ 142.6$ million in 2017 driven by trade taxes. Donor grants almost doubled to $\$ 103.6$ million in 2017 from $\$ 55.3$ million in 2016 - a remarkable performance with $85 \%$ of the commitments being realized compared to only $50 \%$ realized in 2016. Despite the improved performance, the government is still struggling with basic challenges in its fiscal operations. Recurrent expenditures account for almost all expenditure, with capital spending accounting for just 3\% of total spending in 2016 and 2017. Weak expenditure controls result in ad hoc cash rationing to ensure a balanced budget and zero accumulation of arrears hence, affecting overall budget execution. Current spending priorities focus on security and administrative services, which account for almost $90 \%$ of total spending hence the crowding-out provision for economic and social services. The security and development nexus needs to be glue by the social cohesion. To agree with Serageldin (1996) "social cohesion is founded on social capital, glue that holds society together. Norms, values, and social relations are the bonds that hold communities together. These are 
the means by which to reach across differences and begin to build trust" (p. 196).

\section{EU Strategic Interests Somalia Security}

Somalia sits on the strategically important corner of the Horn of Africa. The region sees a considerable amount of maritime activities - it is an important commercial shipping route and has large offshore marine resources - fish stocks and potential offshore oil and gas deposits. In the past ten years, Somalia emerged as the world's foremost source of piracy. International naval presence has suppressed piracy even though it is not eradicated as it is assessed that intent and capacity remain. Enhancing Somali owned maritime security and law enforcement capacities, in line with the Somali National Security Policy, is necessary. However, there is a growing understanding that maritime crime, linked to transnational organised crime, must be understood in a wider context and needs to be addressed on land the sea.

Somalia is also an important source (and transit) country of migration to Europe. Continued or increased instability in Somalia, directly and indirectly, affect the EU through (illegal) migration, spill-over of conflicts, organised crime, a proliferation of small arms and light weapons, as well as terrorism. In the context of migration, support to the security sector could contribute to the positive implementation of the Valletta Plan of Action of November 2015.

The EU engagement in Somalia has been intensified over the years and the EU remains the largest donor in terms of both political engagement and financial and technical support. The EU has played a leading role in the five compact priorities - Inclusive Politics, Security, Justice, Economic Foundations and Revenues and Services. The most notable financial support is directed at supporting AMISOM, where the African Peace Facility (APF) has provided support to soldier's allowances and other issues since the launch of the mission amounting to over $€ 1.1 \mathrm{~B}$ since its launch in 2007. The African Peace Facilities was founded to respond to the African leader's request of support and it is financed through the European Development Fund in support of the African Union's and the African Regional Economic Communities peace and security process. Although with a broader pan-African remit, most of its funds have been principally dedicated to AMISOM however also Mali and the Lake Chad region benefitted of the APF funds to fight Boko Haram.

The EU acknowledged the need to engage in the security sector in Somalia as an instrumental factor in the stabilization of Eastern Africa and for the overall fight against extremist terrorism that is challenging international peace and security. It is also a rallying point for some of the neighboring countries, joint efforts in Somalia can contribute to developing a more cooperative regional approach towards security including the greater efforts in the provision of basic services in rescued areas to highlight the benefits of legitimate authorities. There are a number of illegal or illicit traffics in the Indian Ocean (arms, humans, drugs, coal, etc.) that remain largely unchecked and that fuel instability in Somalia and beyond. It is known by now that the long-term battle against AS, and for the establishment of state authority more generally, will be achieved through the provision of the rule of law. This argues strongly for international community engagement with a focus on supporting the security apparatus at the central and regional levels, including integrated non-state security actors. The strategic objectives for the EU are unchanged in relation to Somalia, however, the new aspect is the increased engagement with non-traditional actors from the Gulf States and their involvement is changing the HoA regional dynamics, not least due to the Yemen situation. Secondly, the relatively unfettered migration seen into Europe of the last years since 2011 has increased the need to look at providing deep stability in source countries. Eritrea is a significant source country, whereas Somalia only accounted for $2 \%$ of the total flows to Europe in 2014. Whilst Somalia is not in itself a major source of migration, it is an important migrant route from Africa to the Arabian Peninsula and, sometimes, onwards to Europe. The migration risk may also arise in Somalia should Yemen further destabilize and cause an inflow of Somali diaspora back into Somalia. The third development has been an increase in radicalization within the $\mathrm{HoA}$, not least due to the rise of the so-called Islamic State (or ISIS), with a risk of further spreading violent extremism into the HoA.

\section{Somali Security and Defence Forces}

There is a general consensus that regional, mostly "irregular" forces are more effective in the fight against Al Shabab than the Somali National Army. This stems partly from the fact that the National Army is perceived as being developed in a mono-clanic way, instead of 
reflecting through its composition the real structure and interests of the country. This raises suspicions at the regional level. The regions themselves have been developing a parallel, more "informal" forces, such as the "darwish". These regional forces are considered by some AMISOM commanders as the most effective in fighting Al Shabab, whereas the National Army is not really contributing to these efforts._The main challenge ahead is, therefore, the integration between regional and federal military efforts. This could comprise building the National Army based on regional forces, or in some way reconverting the regional forces into robust police that will assist in the stabilization of areas recovered from Al Shabab control or combinations of these options. This key issue needs to be tackled head-on by the Somali authorities and reflected on an agreed "security and defence architecture". In addition, security transformation implies civilian oversight of security forces and to offer an "alternative paradigm" as Olowama Ismail considers that

while the principle of civilian rule over the military or more specific operational issues is often tackled in security reform processes, the larger question of defining new national security priorities is not always considered comprehensively and consultative. The priorities are often assumed or defined by an exclusive cohort of national security and political actors. A gendered lens on national security and reform however provides an alternative paradigm and frame of reference. By virtue of directing attention towards individuals and sociocultural contexts, it sheds light on security from the standpoint of the recipient, not the providers.

Somalia has posed a key security challenge for the international community in recent decades. However, the 22,000-strong AMISOM force has helped to stabilize the country somehow making notable gains against AS. Notwithstanding the force's successes, AMISOM's funding was cut by 20 percent in 2018 due to the lack of funding and 20,000 AMISOM troops should be drawdown by 2020 . Uganda has announced that it will pull its approximately 6,700 troops from Somalia in 2018 and the same goes for Kenya, Burundi, Ethiopia, and Djibouti. However, in a meeting in Kampala last March 2018 the Head of State from Uganda, Kenya, Burundi, Ethiopia, and Djibouti met to discuss the serious repercussion AMISOM drawdown could have and in a communiqué Uganda's foreign minister, "Sam Kutesa, said that the decision to drawdown the AMISOM troop taken in 2017 is not realistic and shall be re-discussed because the draw-down would lead to a reversal of the gains made by AMISOM." It is, in fact, uncertain if the Somali National Army and the Somali National Police will be able to fully take up AMISOM functions and fight against Al Shaabab. AS has not been defeated yet, and security concerns remain pre-eminent to allow for development and sustainability in Southern Somalia. Hence, the security umbrella provided by AMISOM, directly supported by the $A U$, the $E U$, and $U N$, is required as the main security guarantor. AMISOM has shifted towards a greater focus on counter-insurgency and in preparing and assisting Somali security forces in the fight against terrorism. External funding and support for AMISOM remain critical as long as it is necessary. The EU's role as the major financial contributor is, however, increasingly problematic and AMISOM, therefore, is working with others, including the $A U$, the troop contributors, the UN, and third countries, to ensure adequate burden-sharing and an eventual exit plan.

The Somali government has to consolidate its power because security gaps remain throughout the country and terrorist attacks still plague its capital and all the other regions, any lapse in security could result in a reversal of Somalia's gains in the last 8 years. The country is fighting an open war, alongside AMISOM, against Islamist that still holds territory. There is a very delicate political balance as regional administrations emerge, federalism has reduced the likelihood of Government political decision-making, corruption increased, and the existing institutions are either a very week or they exist in name only. There is growing fatigue within AMISOM and the broader international community to continue a military offensive against AlShabaab when the long-term solution lies in local governance structures and law-enforcement capacity within the regional administration; AMISOM fatigue, necessitating a rapid shift to civilian law-enforcement and transition efforts from AMISOM to the SNA.

\section{Conclusion}

Somalia has been often the victim of its geography, from the time of the colonial power to the Cold War. The most contemporary regional and international powers made no attempts to prevent and moved from the Cold War era to intra-federal state conflicts through a peaceful process transition: from an authoritaria 
regime to multi-party democracy and the entrenchment of economic liberalism. Somalia collapses and has been unable to successfully manage its rebuilding. To achieve peace among all Somalis, regardless of creed, ethnic origin, and social status there must be a nation-building process within the Etat de Droit and the implementation of a constitutional democracy in which the Federal States are fully supported and sustained by the central government in a joint effort to implement a new social contract. It's the application of the principle of constructivism. In this regard, Nye considers that "constructivism draws on differences by which leaders, people, and culture alter their preferences, shape their identities and learn new behaviors...Constructivism suggests that concept such as nations and sovereignty that give meaning to our lives as well as our theories are socially constructed not just out there but as a permanent reality." There must be full respect for human rights and governance accountability to the citizens while ensuring socio-political stability. It is unquestionable that President Farmaajo is committed to world peace and the preservation of world order engendered and sustained by a renewed domestic politics and through harmonious relations with neighbouring countries and the international community. Somali's peace process is preceding building blocks and addressing the root causes of the social conflict being political, economic or social including the challenges of any incoming factor either through a political resolution including the existence of non-state actors. Non-state actors formed in the absence of state security actors have been left behind to radicalize because of their exclusion from the political process and the socio-economic development. Kizito Sabala, Aisha Ahmad \& Edwin Rutto agree that

Post Conflict, peace building is a multidimensional process of complex and social, economic, military and political recovery in countries emerging out of conflict or civil war. Peacebuilding involves engaging various stakeholders; including sub-and para-state militias in order to resolve ongoing disputes between the warring factions. Moreover, peacebuilding includes a variety of social recovery aspects, which target both civilians and militiamen in seek reconciliation between the victims and the aggressors.

Somali's governance shall represent and legitimize the Constitution and widely respond to the voter's demand.
As federalism continues to develop in Somalia, the role and significance of regional administrations continue to grow, especially in relation to security and defense. Their capacity to deliver services to citizens within the Rule of Law is essential to stabilize the country and address criminality, including piracy and other forms of transnational and organised maritime crime. This capacity needs to begin from the governance structures of the regional administrations and be translated into an institutional capacity for local law-enforcement agencies. Security for the population is provided and sustained in local communities through the efforts of local law enforcement. The Federal Government in Mogadishu has to create the conditions and frameworks for this to happen. The increasing importance of regional administrations (Federal Member States) is crucial. Somali's government shall continue its commitment to establish unified, capable, accountable, and right based Somali Federal institutions, which could provide basic safety and security for its citizens and accountable and sustainable financial institutions. It shall create a more secure, safe and accountable Somalia able to maintain peace within its borders and with its neighbors and restoring and maintaining internal security. The Somali's government shall protect its civilians, with special attention to securing the rights of women, youth, and children increasing equitable access to justice and contributing to the implementation of the rule of law, applying human rights standards and adhering to international humanitarian law. In this process, social cohesion is the key intervening variable between social capital and social conflict. Strong social cohesion reduces the risk of social disorganization, fragmentation, and exclusion that may lead to aggression and violence (Genge 2001:23). Most disturbing, however, is the very real possibility that Somalia's fragile security progress could be undone by mismanagement of the political situation.

Violent extremism and terrorism pose a threat, both within Somalia and to the wider region, as witnessed by attacks in Kenya and Uganda. Gulf influence on Somali and Horn politics has grown and is likely to continue to grow as wider regional dynamics involving other key partners such as Turkey, Ethiopia and recently Egypt play out in Somalia. IGAD and the member states in the Horn of Africa, legitimized by the AU Convention on the Prevention of Terrorism should address terrorism regionally and in a comprehensive manner. 


\section{References}

Gardner, J. \& El Bushra, J. (2004). Somalia - The Untold Story. Pluto Press, London, UK.

Genge, C. (2001). 'Learning For Social Cohesion'. Eudcation 870 (9-13). (Online) Available at:www.unix.cit.unmass.educ870/postconflictpapers.

Hampson, F. O. (2008). Human Studies. In Paul D. Williams (Ed.), Security Studies: An Introduction (pp. 229-289). New York: Routledge.

International Crisis Group (ICG) 2018, Averting War in Northern Somalia, ICG, Brussels, Belgium.

Joseph S. Nye. Jr. (2009). Understanding International Conflicts: An Introduction to Theory and History. Harvard University, USA.

Kapteijns, L. (2013). Clan Cleansing in Somalia: The Ruinous Legacy of 1991. University of Pennsylvania Press, Philadelphia, Pennsylvania.

Lewis I. M. (2002). A Modern History of Somalia. Ohio University Press, Scott Quadrangle, Athens, Ohio, USA.

OECD. (2009). Conflict and Fragility. Armed Violence Reduction: Enabling Development. OECD.

Olowale I. (2008). Enabling Local Owneship : Participation and Capacity Building in SSR. Local Ownership and Security Sector Reform, Geneva Centre For the Democratic Control Of Armed Forces (DCAF). Transaction Publishers, Rutgers University, NJ, USA.

Peter L. (2008). Peace Studies. In Paul D. Williams (Ed.), Security Studies: An Introduction (pp. 73-89). New YorK: Routledge.

Sabala, K., Ahmad, A. \& Rutto, E. (2008). The Somali Peace Process from Arta to Eldoret to Mbagathi Opportunities \& Challenges edit by James Curry in The Resolution of African Conflicts: The Management of Conflict Resolution \& Post Conflict Reconstruction. Unisa Press, Pretoria, SA \& Athens, Ohio, USA.

Saub, E. (1989). The Roots of Evil. The Origin of Genocide and Groups Violance. New York, Cambridge University Press.

Seregelding I. (1996). Sustainability as Opportunity, and the Problem of Social Capital'. The Brown Journal of World Affairs 3 (2): 187-203.

World Bank Report. (2018). The World Bank in Somalia' WB. 
The Forgotten Somalia: A Key Factor for Peace and Stability in the Horn of Africa 